\title{
PSIGOLOGIESE KRAGTE EN DIE EFFEKTIWITEIT VAN WERKSPANNE IN 'N CHEMIESE NYWERHEID
}

\author{
JH BUITENDACH \\ MW STANDER \\ WorkWell: Research Unit for People, Policy \& Performance \\ North-West University, School of Behavioural Sciences \\ Vaal Triangle Campus
}

\begin{abstract}
Psychological forces and the efficiency of work terms in a chemical industry. The aim of this study was to determine the possible relationship between team effectiveness as measured by job satisfaction and interpersonal trust on the one hand, and psychological strengths as measured by sense of coherence, self efficacy, and locus of control on the other hand. The Minnesota Satisfaction Questionnaire, Interpersonal Trust Scale, Sense of Coherence Questionnaire, Locus of Control Questionnaire and Self-efficacy Questionnaire were administered to 66 team members in the different branches of a chemical industry. An availability sample was used in this research. The results of the empirical study confirm a correlation of moderate effect between job satisfaction and self-efficacy of members of the work teams. A moderate correlation was also found between an external locus of control and interpersonal trust of members of work teams.
\end{abstract}

\section{OPSOMMING}

Die doelstelling van hierdie studie was om die moontlike verband tussen spaneffektiwiteit, soos gemeet deur werkstevredenheid en vertroue aan die een kant, en psigologiese kragte soos gemeet deur koherensiesin, selfdoeltreffendheid en lokus van beheer aan die ander kant, te bepaal. Die Minnesota Werksteveredenheidvraelys, die Interpersoonlike Vertrouevraelys, Lewensoriëntasievraelys, die Selfdoeltreffendheidsvraelys en Lokus van Beheervraelys is in ' $n$ organisasie binne ' $n$ chemiese nywerheid op 66 lede van werkspanne afgeneem. Die empiriese ondersoek is in 'n organisasie binne 'n chemiese nywerheid op 66 lede van werkspanne gedoen. Daar is van 'n beskikbaarheidsteekproef gebruik gemaak. Daar is gevind dat daar 'n prakties betekenisvolle verband tussen werkstevredenheid en selfdoeltreffendheid van lede van die werkspanne bestaan. 'n Matige verband is ook tussen ' $n$ eksterne lokus van beheer en interpersoonlike vertroue van lede van die werkspanne gevind.

\section{SYNOPSIS}

South African organisations are known to go through rapid change as a result of globalisation. There is a movement away from traditional autocratic and paternalistic organisational climate towards a culture of increased worker participation. Within the new organisational culture the implementation of workgroups is becoming critical since this development is seen as a way of increasing organisational effectiveness. A further aspect that requires attention within a new, flatter organisational structure is that of psychological optimisation of the employee.

The conceptual constructs of work satisfaction, interpersonal trust, sense of coherence, self-effectiveness and locus of control have been gleaned from a literature study. The empirical aim of this research was to consider and find correlations between issues of team effectiveness (measured in terms of work satisfaction and trust) on the one hand, and psychological strengths (measured in terms of sense of coherence, self-effectiveness and locus of control) on the other hand.

A survey design was used to test the research hypothesis. The subject group comprised 66 members of various workgroups. These people answered questionnaires. Work satisfaction was measured on the Minnesota General Satisfaction Inventory Scale; trust on the Interpersonal Trust Scale; sense of coherence on the Sense of Coherence Inventory; self-effectiveness on the Self-effectiveness Inventory and locus of control on the Locus of Control Inventory.

With respect to job satisfaction, the results of the enquiry indicated that there was no positive connection between work satisfaction, sense of coherence, internal locus of control and external locus of control. On the locus of control inventory there was a positive connection between sense of coherence, self-effectiveness and autonomy. Furthermore, with reference to trust, the results of the study indicate a positive connection between trust and self-

Versoeke vir afskrifte moet gerig word aan: JH Buitendach, Navorsingsprogram Menslikehulpbron-bestuur vir Ontwikkeling, PU vir CHO, Privaatsak X60001, Potchefstroom, 2520 effectiveness, but not between trust, sense of coherence, internal locus of control, external locus of control and autonomy.

The empirical investigation found that there was a practically meaningful difference between individuals with a higher indication of work satisfaction and individuals with a lower indication of work satisfaction with respect to self-effectiveness.

Canonical correlations were used to determine the relationship between interpersonal trust and job satisfaction, interpersonal trust, sense of coherence and self-efficacy. It was found that the total score of locus of control correlates highly with the concepts job satisfaction, sense of coherence and self-efficacy.

Regression analysis was done and it was concluded that the concepts showed non-linear relationships and that further research was needed.

Internasionale mededinging lei daartoe dat ondernemings wêreldwyd tans poog om hul effektiwiteit te verhoog. Die veranderinge wat op die tegnologiese, ekonomiese en sosiale vlak plaasvind en die druk om mededingend op die wêreldmark te wees, vereis dat ondernemings moet wegbeweeg van die outokratiese en paternalistiese vorm van bestuurstyl na 'n meer deelnemende benadering (De Waal, 1997; Mclagan \& Nel, 1996). Die implikasie hiervan is volgens bovermelde skrywers dat die fokus verskuif na groepsdeelname en spaninteraksies. Binne die proses van organisasievernuwing word die implementering van werkspanne al hoe meer aktueel (Neubert \& Mount, 1998; Sundstrom, De Meuse \& Futrell, 1990).

Lawler (1996) is van mening dat werkspanne dit vir ondernemings moontlik maak om meer op die verwagtings van interne en eksterne kliënte te konsentreer en sodoende hul effektiwiteit te verhoog.

Spaneffektiwiteit word deur Sundstrom et al., (1990) omskryf as bestaande uit prestasie en spanlewensvatbaarheid. Onder prestasie word verstaan dat 'n aanvaarbare of kwaliteitproduk of -diens aan eksterne en interne kliënte gelewer word. Met 
spanlewensvatbaarheid word werkstevredenheid en deelname van die spanlede bedoel. Vir hierdie navorser verwys spaneffektiwiteit na 'n verskeidenheid faktore, onder andere interspansamewerking, oop kommunikasie, deursigtigheid, duidelike rolle, doelwitte en volwassenheid (Sundstrom et al., 1996).

Cohen, Ledford en Spreitzer (1996) meld dat verskillende teoretici 'n algemene model van spaneffektiwiteit voorstel, wat nie net op selfgerigte werkspanne nie, maar op alle werkgroepe van toepassing is. Hierdie soort modelle sluit tipies kategorieë van voorspellers in. Die voorspellers van die verskillende modelle oorvleuel dikwels met mekaar en sluit voorspellers soos werksontwerp, groepkenmerke, organisatoriese konteks en groepprosesse in (vgl. Gladstein, 1984; Hackman, 1987; Sundstrom et al., 1990). Die model van Cohen et al. (1996) het vier kategorie, van voorspelbare veranderlikes gemeld wat moontlik 'n invloed op spaneffektiwiteit kan uitoefen, naamlik groeptaakontwerp, groepkenmerke, aanmoediging van toesighouergedrag en werknemersbetrokkenheidkonteks.

In hierdie navorsing word spaneffektiwiteit beskou as die resultaat van die interaksie tussen die onderskeie spanlede (met elke individu wat in die span is se unieke psigologiese kragte), die ervaring van werkstevredenheid en die mate van vertroue wat ervaar word. Afgesien van die interne kragte is daar ook eksterne kragte, soos onder andere die kliënte, die ekonomie en die medewerkers in die mark. Voorts bestaan daar 'n aantal komponente wat die effektiwiteit van die werkspan kan beïnvloed, onder andere die doelwitte, groepsamestelling, asook die manifestasie van leierskap binne die groep. Die navorser is van mening dat spaneffektiwiteit nie deur 'n enkele meetinstrument bepaal kan word nie. Die rede daarvoor is dat daar verskeie voorspellers vir spaneffektiwiteit is, soos werkstevredenheid, produksie, vertroue, en psigologiese kragte van die spanlede. Spaneffektiwiteit is egter interafhanklik van die totale onderlinge organisatoriese netwerk van bedrywighede. In hierdie navorsing word spaneffektiwiteit gemeet deur die vlakke van werkstevredenheid en interpersoonlike vertroue van die werknemers en psigologiese kragte deur die vlakke van koherensiesin, selfdoeltreffendheid en lokus van beheer.

Die verband tussen spaneffektiwiteit en psigologiese optimaliteit is van betekenisvolle belang in hierdie navorsing aangesien die fokus van hierdie navorsing die vasstelling is van die verband tussen die psigologiese kragte (soos gemeet aan koherensiesin, selfdoeltreffenheid en lokus van beheer) enersyds en spaneffektiwteit (soos gemeet aan werkstevredenheid en interpersoonlike vertroue) andersyds.

In hierdie navorsing word die disposisionele oorsake van werkstevredenheid vanuit 'n salutogenetiese paradigma (wat fokus op die oorsprong van gesondheid) (Antonovsky, 1987; Strümpfer, 1990) of fortigene paradigma (wat fokus op oorsake van sterktes) gebruik (Strümpfer, 1995). Strümpfer $(1990,1995)$ het 'n aantal konstrukte hersien wat onafhanklik ontwikkel het maar tog deel vorm van die fortigene paradigma, insluitende koherensiesin (Antonovsky, 1987), gehardheid (Kobasa, 1982) en potensie (BenSira, 1979, 1988). Konstrukte soos selfdoeltreffendheid (Bandura, 1989) en interne-eksterne lokus van beheer (Rotter, 1966) kan as fortigene verband beskou word. Hierdie studie handel oor die verband tussen spaneffektiwiteit (soos gemeet deur werkstevredenheid en interpersoonlike vertroue) aan die een kant en drie disposisionele faktore, naamlik koherensiesin, selfdoeltreffendheid en lokus van beheer, aan die ander kant.

\section{Koherensiesin}

Die konstruk "koherensiesin" is deur Antonovsky (1987) ontwikkel. Koherensiesin word omskryf as 'n omvattende oriëntasie wat dui op die mate waarin 'n persoon 'n langdurige en dinamiese vertroue het dat hy/sy interne en eksterne omgewing voorspelbaar is en dat daar ' $n$ groot waarskynlikheid sal bestaan dat dinge so goed as verwag kan word, sal uitwerk. Dit beïnvloed waarskynlik ' $n$ individu se persepsie van stimuli.
Met hoë koherensiesin word die stimuli ervaar as verstaanbaar, binne die beheer van die individu en betekenisvol.

Die definisie van koherensiesin sluit drie dimensies in wat gesamentlik die konsep verteenwoordig, naamlik verstaanbaarheid, hanteerbaarheid en betekenisvolheid (Antonovsky, 1987).

- Verstaanbaarheid verwys na die mate waarin die individu interne sowel as eksterne stimuli as duidelik geordende, gestruktureerde en konsekwente inligting ervaar. Die stimuli word ervaar as verstaanbaar en kognitief sinvol.

- Hanteerbaarheid verwys na die mate waarin die individu gebeurtenisse as hanteerbaar en selfs as nuwe uitdagings beskou.

- Betekenisvolheid dui op die mate waarin die individu ervaar dat die lewe emosioneel, eerder as kognitief sin maak.

Antonovsky (1987) wys daarop dat die drie komponente nou verwant is. Suksesvolle hantering van lewenseise hang egter af van koherensiesin as geheel en kan nie net op een of twee van die komponente geskoei wees nie. Om hierdie rede word die enkeltelling op die vraelys (Orientation to Life Scale van Antonovsky, 1987) gebruik en nie die onderskeie subtellings nie.

Strümpher en Louw (1989) het bevind dat deelnemende besluitneming korreleer met 'n meting van werkstevredenheid en minder gevoelens van hulpeloosheid by manlike plaaswerkers met 'n lae koherensiesin.

Coetzee en Rothman (1999) het bevind dat daar 'n matige verband tussen koherensiesin en werkstevredenheid van bestuurders bestaan.

Buiten bogenoemde het verskeie studieprojekte deur nagraadse studente aan die Universiteit van Kaapstad ook 'n betekenisvolle korrelasie tussen koherensiesin en werkstevredenheid getoon (vgl. Strümpher, 1995; Strümpher, Fritz \& Page, 1991). Danana, Gouws en Viviers (1998) het bevind dat daar 'n matige korrelasie $(r=0,47)$ tussen koherensiesin en werkstevredenheid bestaan.

'n Werknemer met 'n sterk koherensiesin behoort dus in staat te wees om sy/haar werksituasie op 'n kognitiewe vlak te verstaan.

\section{Selfdoeltreffendheid}

Die konsep "Selfdoeltreffendheid" is deur Bandura (1982, 1989) ontwikkel. Hierdie konstruk verwys na die oordele van individue rakende hulle vemoëns om vereiste gedrag te beoefen. Wood en Bandura, (1989, p. 408) omskryf selfdoeltreffendheid as “...beliefs in one's capabilities to mobilise the motivation, cognitive resources, and courses of action needed to meet given organisational demands". Die rol van kognisie, daardie aspek van die verstandelike funksionering wat bewuste gedagteprosesse (insluitende sleutelelemente soos redenering, probleemoplossing, besluitneming en oordeelsvermoë) insluit, geniet spesiale beklemtoning binne hierdie konseptuele raamwerk. In die werksituasie sal individue wat oor selfdoeltreffendheid beskik, glo dat hulle suksesvol sal wees met die meeste take en verantwoordelikhede by die werk (Gardner \& Pierce, 1998).

Volgens Gardner en Pierce (1998) asook Judge, Locke, en Kluger (1998) kan selfdoeltreffendheid vanuit 'n algemene sowel as 'n spesifieke sienswyse bespreek word. Taakspesifieke selfdoeltreffendheid is ' $n$ staatgebaseerde verwagting oor oordeel rakende die moontlikheid van suksesvolle taakprestasie gemeet onmiddellik voordat enige pogings op die taak spandeer is. Selfdoeltreffendheid kan ook beskou word as 'n algemene, stabiele kognisie waaroor die individu beskik en die vermoë wat die individu het om 'n taak suksesvol te voltooi (Eden \& Zuk, 1995). Dit is dus 'n kragtige motiveerder.

Gist (1987), Gist en Mitchell (1992) voer aan dat 'n individu se selfdoeltreffendheidsoordele van tyd tot tyd kan verskil op grond van nuwe inligting en ondervinding. Selfdoeltreffendheid kan dus as 'n dinamiese konsep beskou word. 
Die primêre gevolg van 'n sterk spesifieke selfdoeltreffendheidspersepsie is volgens Sadri en Robertson (1993) verhoogde taakprestasie. Algemene selfdoeltreffendheid word gestel as 'n sterk determinant van spesifieke selfdoeltreffendheid (Eden, 1988). Volgens Bandura (1989) twyfel werknemers met lae vlakke van selfdoeltreffendheid oor hulle vermoëns, skram weg van moeilike take, het lae aspirasies en swak verbondenheid tot doelstellings. Judge et al., (1998) kom tot die gevolgtrekking dat selfdoeltreffendheid 'n indirekte invloed op werkstevredenheid het, in die sin dat dit persepsies van werksbydraes beïnvloed, wat 'n invloed het op werkstevredenheid.

Vir die doeleindes van hierdie navorsing word selfdoeltreffendheid omskryf as die oortuiging wat 'n individu handhaaf rakende sy/haar vermoëns om 'n spesifieke taak uit te voer. Sodanige individu beskik oor genoeg selfkennis om te bepaal hoeveel tyd en energie aan 'n spesifieke taak spandeer moet word. Die voorafgaande is vir die onderhawige navorsing van groot belang, aangesien die selfdoeltreffendheidsoortuigings wat ' $n$ individu het die spaneffektiwiteit van 'n werkspan kan beïnvloed.

Opsommend kan gesê word dat selfdoeltreffendheid beïnvloed word deur ' $n$ individu se ervaring en persoonlikheidskenmerke, sowel as taakspesifieke faktore. Die sterkte van die selfdoeltreffendheid sal ' $n$ invloed op prestasie hê en vorige ervaring bly een van die beste voorspellers van selfdoeltreffendheid (Wolf, 1992). Vir die doeleindes van hierdie navorsing kan van die standpunt uitgegaan word dat selfdoeltreffendheid van spanlede 'n effek op prestasie sal hê.

\section{Lokus van beheer}

Lokus van beheer verwys na die mate waarin die individu glo dat hy/sy gebeure in sy/haar lewe beheer (interne lokus van beheer) of dat die omgewing en noodlot gebeure beheer (eksterne lokus van beheer) (Rotter, 1966).

Die begrip lokus van beheer het vanuit die sosiale leerteorie (Rotter, 1966) en attribusieteorie (Heider, 1958) ontwikkel. Die sosiale leerteorie gaan van die standpunt uit dat versterking van gedrag tot 'n verhoging van die verwagting lei dat bepaalde gedrag of 'n besondere gebeurtenis in die toekoms weer deur daardie versterking gevolg sal word (Rotter, Chance $\&$ Phares, 1972). Schepers (1995) meen dat die konstruk lokus van beheer uit drie afhanklike faktore, naamlik interne lokus van beheer, eksterne lokus van beheer en outonomie, bestaan. Wanneer die individu waarneem dat die gebeurtenis plaasvind as gevolg van eie gedrag, vermoëns of persoonlike eienskappe, word dit as 'n interne lokus van beheer gedefinieer. Indien die individu waarneem dat die versterking op eie gedrag volg, maar nie die gevolg van eie gedrag is nie, word dit tipies waargeneem as die resultaat van geluk, die noodlot of die invloed van andere, of dit word as iets onvoorspelbaars waargeneem. Indien die gebeurtenis só waargeneem word, word dit gedefinieer as 'n eksterne lokus van beheer. Outonomie kan omskryf word as die mate waartoe die individu op sy/haar eie kan funksioneer, sonder dat daar voortdurende toesig is (Lefcourt, 1966; Phares, 1976).

Die individu met 'n interne lokus van beheer sal moontlik voel dat hy/sy die situasie by die werk kan hanteer omdat hierdie situasie beskou word as binne persoonlike beheer (Judge, Locke, Durham \& Kluger, 1998). Aan die ander kant sal die individu met 'n eksterne lokus van beheer minder in staat wees om frustrasies by die werk te hanteer en sal geneig wees om te onttrek of aggressief te reageer (Rahim \& Psenicka, 1996; Spector, 1982, 1986, 1988). Die individu met 'n interne lokus van beheer is volgens Mayer en Sutton (1996) meer suksesvol in interpersoonlike verhoudinge as die individu met 'n eksterne lokus van beheer. Die individu met 'n eksterne lokus van beheer is geneig om op ander persone te wag vir rigtinggewing.
Spector (1986) bevind dat hoë vlakke van veronderstelde beheer verband hou met hoë vlakke van werkstevredenheid, verbondenheid en betrokkenheid en lae vlakke van stres, afwesigheid en personeelomset. Die studies van Garson en Stanwyck (1997) en Judge et al. (1998) bevestig 'n verband tussen 'n interne lokus van beheer en werkstevredenheid. 'n Individu met ' $n$ interne lokus van beheer blyk meer tevrede met sy werk te wees, weens sy veronderstelde vermoë om situasies te beheer.

Moerdyk (1986) toon aan dat daar 'n korrelasie bestaan tussen eksterne lokus van beheer aan die eenkant, en passiwitieit, stadige besluitneming en onrealistiese verwagtinge van die werksomgewing aan die ander kant. Daarby vind Rahim en Psenicka (1996) dat persone met 'n eksterne lokus van beheer nie in staat is om die druk, onsekerhede en uitdagings van 'n veeleisende werksituasie te hanteer nie.

Navorsing gedoen deur Latham en Yukl (1976) dui aan dat die individu met ' $n$ interne lokus van beheer beter presteer met moeilike take wat aan hom/haar opgedra word as die individu met 'n eksterne lokus van beheer. Volgens Kren (1992) glo die individu met ' $n$ interne lokus van beheer dat sy/haar gedrag die uitkoms van gebeure beïnvloed. Hierteenoor is die individu met 'n eksterne lokus van beheer meer passief.

\section{Die verband tussen koherensiesin, lokus van beheer en selfdoeltreffendheid}

In die literatuur is verskeie navorsing gevind wat ' $n$ verband tussen selfdoeltreffendheid en lokus van beheer aantoon. Sherer et al. (1982) is van mening dat die individu met 'n hoë vlak van selfdoeltreffendheid, sukses sal toeskryf aan sy/haar pogings en hierdie neiging sal noodwendig selfdoeltreffendheid verhoog.

Volgens Lefcourt (1982) en Rotter (1966) twyfel die individu met 'n eksterne lokus van beheer aan sy/haar eie doeltreffenheid. Beide selfdoeltreffendheid en lokus van beheer het te make met beheer en is kognitiewe konstrukte (Rotter, 1996).

Kalimo en Vuori (1990) is van mening dat koherensiesin konsepte insluit wat ook in die lokus-van-beheerteorie gevind kan word. Koherensiesin verwys na 'n geïnternaliseerde gevoel van beheer, wat ook riglyne bied vir oriëntasie vir toekomstige gebeure. Koherensiesin help dus die individu om die verskillende fasette van beheer en hulle gevolge te verstaan. Dit is in hierdie verband dat koherensiesin en lokus van beheer met mekaar 'n verband toon, aangesien beide gerig is op die veronderstelde gesondheidsoriëntasie (Seeman \& Seeman, 1983).

Die verband tussen selfdoeltreffendheid en koherensiesin is interessant, aangesien selfdoeltreffendheid nie primêr in die fortigene paradigma gekonseptualiseer word nie. Selfdoeltreffendheid, net soos koherensiesin, is gemoeid met die individuele ervaring van kragtigheid in die individu se eie wêreld (Breed, 1997). Volgens Antonovsky (1987) toon die komponente van koherensiesin ooreenkomste met die selfdoeltreffendheidskonstruk.

Die motivering vir die bestudering van psigologiese kragte in hierdie navorsing kan gevind word in die werk van Gould (1993). Hierin word gemeld dat betekenisvolle psigologiese sterktes gereflekteer word as 'n verlenging van die individu wat na psigologiese optimalisering streef.

\section{Spaneffektiwiteit}

Spaneffektiwiteit is vir die doeleindes van hierdie navorsing volgens die model van Cohen en Bailey (1997) beskou as bestaande uit prestasie-, houdings- en gedragsuitkomste. In hierdie studie is slegs gekonsentreer op die houdingsuitsette, wat gekenmerk kan word aan werkstevredenheid en vertroue. Dit is die navorsers se mening dat in 'n voortdurend veranderde werksomgewing hierdie twee houdingsuitsette van besonderse belang is. Waar voortdurende herstrukturering, skepping van platter strukture en minder sekuriteit bestaan is mense geneig om minder vertroue en werkstevredenheid te ervaar. 
Hoewel daar enkele variasies by die definiëring van werkstevredenheid voorkom, is daar tog konsensus (Cranny, Smith \& Stone, 1992; Kreitner \& Kinicki, 1998) daaroor dat werkstevredenheid 'n affektiewe reaksie op werk is, wat voortspruit uit posbekleërs se vergelyking van werklike uitkomste in die werk met dié wat hulle in die werk verlang of verwag. Lofquist en Davis (1969) meen dat werkstevredenheid 'n funksie is van die ooreenstemming tussen die werksomgewing en die individu se behoeftes. Locke (1976) omskryf werkstevredenheid as 'n aangename of positiewe emosionele toestand as gevolg van die individu se evaluering van sy/haar werk.

Baron, Byrne en Kantowitz (1980) beweer dat die individu wat in 'n organisasie werk, spoedig bepaalde ingesteldhede teenoor die werk, die toesighouer, medewerkers en vergoeding ontwikkel. Hierdie ingesteldhede word werkstevredenheid genoem. Volgens Weiss, Davis, England en Lofquist (1967) wil elke persoon harmonie met die werksomgewing bereik en in stand hou. Harmonie kan omskryf word met verwysing na die individu se voldoening aan die vereistes van die werksomgewing, en die werksomgewing wat op sy beurt die individu se vereistes bevredig (Cook, Hepworth, Wall \& Warr, 1981). Werkstevredenheid is dus ' $n$ positiewe of negatiewe houding (emosionele reaksie) wat teenoor die werk ontstaan, omdat die werknemer sekere behoeftes het waaraan die pos moet voldoen en die werknemer vergelyk dan sy/haar verwagte uitkomste met dit wat werklik in die werksituasie ontvang word. Indien dit wat werklik ontvang word, minder is as wat die individu verwag, ontstaan 'n negatiewe affek ten opsigte van die werk, wat werkontevredenheid tot gevolg het. Indien die uitkomste egter aan die individu se verwagtinge voldoen, of dit selfs oortref, word 'n positiewe affek teenoor die werk gehuldig wat 'n aanduiding van werkstevredenheid is.

Werkstevredenheid is 'n sleutelaspek wat beide die individu en die organisasie beïnvloed. Volgens Chiu en Kosinki (1997) het 'n werknemer se vlak van werkstevredenheid 'n invloed op sy/haar emosies, gedrag en werksprestasie. Robbins (1998) omskryf werkstevredenheid as "a general attitude toward one's job; the difference between the amount of rewards workers receive and the amount they believe they should receive".

Roznowki en Hulin (1992) is van mening dat die meting van werknemers se werkstevredenheid van die waardevolste data is waaroor die bestuur van 'n organisasie kan beskik. Daar is verskeie navorsing gedoen rakende die verhouding tussen werkstevredenheid en ander organisatoriese veranderlikes. Rothmann en Agathagelou (2000) het gevind dat daar 'n verband van groot effek tussen lokus van beheer (interne lokus van beheer, eksterne lokus van beheer en outonomie) en werkstevredenheid by senior polisiepersoneel bestaan. Coetzee en Rothmann (1999) het ook 'n matige verband tussen werkstevredenheid en koherensiesin by bestuurders gevind.

McAllister (1995) dui aan dat onlangse navorsing rakende organisasiegedrag die belangrikheid van interpersoonlike vertroue as 'n kriterium vir individuele en organisatoriese effektiwiteit beklemtoon. Rotter (1966) bevind dat die belangrikste faktor in die effektiwiteit van enige komplekse sosiale organisasie die gewilligheid van die individue is om mekaar te vertrou.

Jones-George en Swap (1982), asook McAllister (1995) meld dat onlangse navorsing rakende organisasiegedrag die belangrikheid van interpersoonlike vertroue as 'n kriterium vir individuele en organisatoriese effektiwiteit beklemtoon. Rotter (1966) wys daarop dat die belangrikste faktor in die effektiwiteit van enige komplekse sosiale organisasie, die gewilligheid van die individue is om mekaar te vertrou.

Binne die organisasie is daar bepaalde faktore soos lojaliteit, openlikheid, integriteit en welwillendheid wat kan bepaal of daar vertroue tussen die werknemer en die organisasie, of meer spesifiek die onderskeie werkspanlede kan bestaan (Mayer, Davis \& Schoorman 1995). Verskeie navorsers, onder andere Kreitner en Kinicki, (1998) asook Sitkin en Roth (1993) aanvaar in beginsel dat vertroue omskryf kan word as 'n oortuiging, houding of verwagting rakende die moontlikheid dat die intensies en die aksies van ander individue goed en aanvaarbaar sal wees. Jones-George en Swap (1982) meld dat vertroue ook handel oor die bereidwilligheid om risiko's te neem. Gambetta (1988) voeg die konstruk kwesbaarheid by hierdie definisie. Om kwesbaar te wees beteken dat iets van belang verloor kan word en dat ' $n$ risiko geneem word. Vertroue beteken, volgens hierdie definisie, nie om ' $n$ risiko per se te neem nie, maar eerder ' $n$ bereidwilligheid om risiko's te neem.

Mayer, Davis en Schoorman (1995) voer voorts aan dat die interpersoonlike aard van vertroue ook een van die aspekte is waaroor meeste navorsers in hierdie raamwerk konsensus het. Rotter (1967, p. 650) omskryf interpersoonlike vertroue as "an expectancy held by an individual or a group that the word, promise, verbal, or written statement of another individual or group can be relied on". Butler en Cantrell (1984) is van mening dat die interpersoonlike aard van vertroue 'n voorvereiste vir samewerking is.

Volgens McAllister (1995) het interpersoonlike vertroue 'n kognitiewe en affektiewe grondslag. Vertroue is kognitief in dié sin dat dit verwys na die feit dat die individu 'n keuse het ten opsigte van wie vertrou word en onder watter omstandighede, en dat die keuse op goeie rede gebaseer is. Vertroue is affektief, aangesien dit uit emosionele bande tussen individue bestaan. Daar word emosionele beleggings in vertrouensverhoudings gemaak in die sin dat ware omgee vir die ander party teenwoordig is, en dat daar geloof in die intrinsieke waarde van die verhouding bestaan. Hierdie emosionele bande vorm die basis vir die vertrouensverhouding.

Hosmer (1995) is van mening dat vrywillige samewerking en uiteindelike voordeel aandui dat daar 'n duidelike assosiasie bestaan tussen 'n definisie van vertroue-in-die-organisasieteorie en die konsep van die goeie in die morele filosofie.

Interpersoonlike vertroue word omskryf as ' $n$ toestand van kognitiewe en affektiewe geloof in die ander party(e) dat die verlangde gedrag geopenbaar gaan word, en dat die ander party(e) doen wat verwag word.

Verskeie navorsing is gedoen rakende vertroue aan die een kant en psigologiese kragte (soos gemeet aan koherensiesin, lokus van beheer en selfdoeltreffendheid) aan die ander kant. In hul navorsing rakende motorbestuurders se selfevaluering van hulle perseptuele en motoriese vaardighede het Lajunen et al. (1998) gevind dat daar 'n verband tussen koherensiesin en vertroue bestaan. Hoe hoër die vlakke van koherensiesin wat ervaar word, hoe hoër die vlakke van vertroue.

\section{METODE}

\section{Navorsingsontwerp}

Die navorsingsonwerp kan geklassifiseer word as 'n opnameontwerp (korrelasionele ontwerp) (Huysamen, 1993). Elke individu in die ondersoekgroep word op dieselfde tydstip ten opsigte van twee veranderlikes gemeet, en die verband tussen hierdie verkrygde metings word bepaal. Die opname-ontwerp is geskik vir hierdie studie, waar dit handel oor die bestudering van verbande wat sonder enige beplande ingreep tussen twee of meer veranderlikes voorkom.

\section{Ondersoekgroep}

Die ondersoekgroep het bestaan uit 66 lede van verskillende werkspanne wat in spanne saamwerk binne 'n chemiese nywerheid. 'n Beskikbaarheidsteekproef is saamgestel uit lede van die verskillende werkspanne. Ongeveer $71 \%$ van die 
ondersoekgroep het uit mans bestaan. Die ondersoekgroep se ouderdomme wissel tussen 20 en 55 jaar, met $45,3 \%$ in die ouderdopmsgroep tussen 25 en 35 jaar. Ongeveer $60,8 \%$ van die ondersoekgroep beskik oor 'n dienstydperk van korter as 10 jaar.

\section{Meetinstrumente}

Vyf vraelyste is in hierdie navorsing gebruik, naamlik die Minnesota Tevredenheidsvraelys (Weiss et al., 1967), Interpersoonlike Vertrouevraelys (Rotter, 1967), Lokus van Beheervraelys (Schepers, 1999), Koherensiesinvraelys (SOC) (Antonovsky, 1987) en Selfdoeltreffendheidsvraelys (Tipton \& Warthington, 1986).

Die Minnesota Tevredenheidskaal is gebruik om deelnemers se werkstevredenheid te meet. Die Minnesota Tevredenheidsvraelys is ontwikkel as 'n meetinstrument van een van die primêre bewyse van werksaanpassing, naamlik werkstevredenheid. Die lang vorm van die Minnesota Tevredenheidsvraelys, wat bestaan uit 100 items (wat saam 20 subskale vorm), is in hierdie ondersoek gebruik. In 'n studie wat deur Rothmann en Agathagelou (2000) onder polisiebeapmtes onderneem is, is ' $n$ Cronbach alfakoëffisiënt van 0,96 gevind.. Dit stem ooreen met die bevinding van Coetzee (1998), wat ook 'n alfakoëffisiënt van 0,96 verkry het ten opsigte van Algemene Werkstevredenheid.

Die Interpersoonlike Vertroueskaal van Rotter (1967) is ontwerp om interpersoonlike vertroue in 'n verskeidenheid situasies te meet. Die skaal bestaan uit 25 items en vertroue word in verskillende velde gemeet, soos byvoorbeeld die politiek, regsgeleerdheid en joernalistiek. Rotter (1967) verkry 'n alfakoëffisiënt van 0,76 . Daar is in die literatuur weinig nuwe meetinstrumente wat interpersoonlike vertroue meet.

Die Lewensoriëntasiesiesinvraelys (LOV) van Antonovsky (1987) bestaan uit 29 items. Antonovsky (1993) het die psigometriese geldigheidsdata van die skaal hersien. Die Cronbach alfakoëffisiënt van die interne konsekwentheid wissel van 0,82 tot 0,95 . Die toets-hertoetsbetroubaarheid van die SOC-vraelys is 0,54 (na twee jaar). Die skaal beskik oor hoë inhoudsgeldigheid asook konstrukgeldigheid.

Die Selfdoeltreffendheidsvraelys (SDV) (Tipton en Worthington, 1984) is ontwerp om te bepaal hoe ' $n$ individu sy/haar vermoëns beoordeel en sy/haar ervaring van persoonlike doeltreffendheid ten opsigte van gebeure in sy lewe reguleer. Tipton en Worthington wys daarop dat dié vraelys gebaseer is op die konsep van geloof, veral geloof in die self. Marais (1997) en Stanley en Murphy (1997) verkry Cronbach alfakoëffisiënte van onderskeidelik 0,71 en 0,83 op die Selfdoeltreffendheidsvraelys.

Die Lokus van Beheervraelys (LVB) van Schepers (1999) is ontwerp om interne en eksterne lokus van beheer en outonomie te meet. Die skaal wat in 1999 hersien is, bestaan uit 88 items. Die drie skale van hierdie meetinstrument is aan ' $n$ item-ontleding onderwerp, en die betroubaarheid daarvan is hoër as 0,80 . Wat die kriteriumverwante geldigheid betref, is bevind dat die vraelys met 'n saamgestelde kriterium van werksukses $(r=0,62)$ korreleer (Bothma \& Scheepers, 1997).

\section{Statistiese prosedure}

Die statistiese ontledings is met behulp van die SAS-program (SAS Institute, 1996) gedoen. Daar is van 'n steekproef gebruik gemaak en dus word van effekgrootes eerder as inferensiële statisitek gebruik gemaak (Steyn, Smit, Du Toit \& Strasheim, 1995). Die produkmoment-korrelasiekoëffisiënt (r) is bereken om die mate waartoe een veranderlike met ' $n$ ander verband hou, te bepaal (Kerlinger, 1986). Volgens Cohen (1988) kan 'n korrelasie (r) beter begryp word deur $\mathrm{r}^{2}$ te bereken. Die kwadraat van die korrelasiekoëffisiënt dui op die proporsie van die variansie in enige van die twee veranderlikes wat voorspel word deur die variansie in die ander veranderlike.
Kanoniese korrelasies is bereken om die verwantskap tussen die drie skale van die LVB en die ander vraelyste (Minnesota Tevredenheidsvraelys, Selfdoeltreffendheidsvraelys, Koherensies-invraelys en Interpersoonlike Vertrouevraelys) te bepaal. Die gebruik van kanoniese korrelasies is toepaslik wanneer gepoog word om die verband tussen twee stelle veranderlikes wat beide op 'n kontinuum gerangskik is, te bepaal (Marriot, 1974).

Aangesien ' $n$ beskikbaarheidsteekproef (wat nie noodwendig verteenwoordigend is van die teikenpopulasie nie) in hierdie ondersoek gebruik is, word die beduidendheid van die bevindings in verband gebring met die praktiese betekenisvolheid eerder as die statistiese beduidendheid daarvan (Steyn, 1999).

'n Afsnypunt van 0,30 (medium effek, Cohen, 1988) is gestel vir praktiese betekenisvolheid van die korrelasie tussen veranderlikes.

\section{RESULTATE}

Beskrywende statistiek ten opsigte van die Minnesota Tevredenheidskaal word in Tabel 1 weergegee.

\section{TABeL 1}

BESKRYWENDE STATISTIEK T.O.V. DIE MINNESOTA WERKSTEVREDENHEIDVRAELYS

VIR DIE TOTALE ONDERSOEKFROEP

\begin{tabular}{|c|c|c|c|c|c|}
\hline SUBFAKTORE & $\mathbf{N}$ & $\mathrm{X}$ & $S$ & MIN & MAKS \\
\hline Totaal & 66 & 484,1 & 79,5 & 336,0 & 681,0 \\
\hline Vermoë & 66 & 25,4 & 5,5 & 9,0 & 35,0 \\
\hline Prestasie & 66 & 26,5 & 5,4 & 8,0 & 35,0 \\
\hline Aktiwiteit & 66 & 25,3 & 6,1 & 11,0 & 34,0 \\
\hline Bevordering & 66 & 20,2 & 7,7 & 5,0 & 35,0 \\
\hline Outoriteit & 66 & 24,6 & 5,4 & 11,0 & 35,0 \\
\hline Maatskappybeleid & 66 & 22,5 & 6,3 & 10,0 & 35,0 \\
\hline Vergoeding & 66 & 19,9 & 6,2 & 5,0 & 35,0 \\
\hline Medewerkers & 66 & 24,1 & 6,2 & 11,0 & 35,0 \\
\hline Kreatiwiteit & 66 & 24,7 & 5,3 & 9,0 & 35,0 \\
\hline Onafhanklikheid & 66 & 26,7 & 4,6 & 16,0 & 35,0 \\
\hline Morele waardes & 66 & 27,0 & 4,9 & 17,0 & 35,0 \\
\hline Erkenning & 66 & 20,6 & 7,1 & 6,0 & 35,0 \\
\hline Verantwoordelikheid & 66 & 25,2 & 5,9 & 11,0 & 35,0 \\
\hline Sekuriteit & 66 & 24,0 & 5,7 & 14,0 & 35,0 \\
\hline Sosiale diens & 66 & 25,9 & 5,4 & 15,0 & 35,0 \\
\hline Sosiale status & 66 & 24,3 & 5,0 & 11,0 & 34,0 \\
\hline Toesighouding - mens & 66 & 22,3 & 7,4 & 9,0 & 35,0 \\
\hline Toesighouding - tegnies & 66 & 23,3 & 6,7 & 8,0 & 35,0 \\
\hline Verskeidenheid & 66 & 25,7 & 5,1 & 11,0 & 35,0 \\
\hline Fisiese werksomgewing & 66 & 26,3 & 6,0 & 11,0 & 35,0 \\
\hline
\end{tabular}

Dit blyk uit Tabel 1 dat die gemiddelde telling van die totale werkstevredenheidvlak van die respondente 484,1 is. Dit dui daarop dat die respondente 'n redelike mate van werkstevredenheid ervaar. Hierdie resultate is hoër as die resultate van Coetzee (1998), wat 'n gemiddelde telling van 459,00 verkry het. Wat die vlak van werkstevredenheid ten opsigte van subfaktore van werkstevredenheid van spanlede betref, kan die afleiding gemaak word dat respondente die minste tevredenheid met hul vergoeding, bevordering en erkenning ervaar. Die meeste tevredenheid word met morele waardes, prestasie en fisiese omgewing ervaar 
TABEL 2

BESRYWENDE STATISTIEK T.O.V. DIE INTERPERSOONLIKE VERTROUE VIR DIE TOTALE ONDERSOEKGROEP

\begin{tabular}{cccccc}
\hline ITEM & N & X & S & MIN & MAKS \\
\hline Totaal & 66,0 & 79,5 & 11,8 & 55,0 & 106,0 \\
\hline
\end{tabular}

Dit blyk uit Tabel 2 dat die interpersoonlike vertroue van die respondente na 'n gemiddelde telling neig. Daar kan dus tot die gevolgtrekking gekom word dat die respondente tot 'n gemiddelde mate interpersoonlike vertroue ervaar.

TABEL 3

BESRYWENDE STATISTIEK T.O.V. DIE KOHERENSIESINVRAELYS VIR DIE TOTALE ONDERSOEKGROEP

\begin{tabular}{lccccc}
\hline ITEM & N & X & S & MIN & MAKS \\
\hline SOC (TOTAAL) & 66 & 133,6 & 15,3 & 105,0 & 183,0 \\
Verstaanbaarheid & 66 & 44,5 & 7,5 & 26,0 & 68,0 \\
Hanteerbaarheid & 66 & 47,0 & 6,7 & 28,0 & 63,0 \\
Betekenisvolheid & 66 & 42,1 & 5,6 & 28,0 & 53,0 \\
\hline
\end{tabular}

Die Lewensoriëntasievraelys bestaan uit 29 items wat op 'n 7 puntskaal aangedui kan word. Die hoogste telling wat op die totale telling verkry kan word is 203. Hoe nader die totale telling aan 203 is, hoe hoër is die koherensiesin. Die totaal van die drie subskale gee 'n aanduiding van die ondersoekgroep se koherensiesin. Gemiddelde tellings op die LOV-vraelys wissel tussen 120 en 150 . Wissing en Van Eeden (1997) het 'n gemiddelde telling van 136,52 en 'n standaardafwyking van 21,68 in 'n ondersoekgroep van 550 respondente verkry. Coetzee (1998) het 'n gemiddelde telling van 143,11 en 'n standaardafwyking van 21,42 verkry. Die gemiddelde telling behaal op die LOV-vraelys in hierdie studie, soos blyk uit Tabel 3 , is 133,60 en die standaardafwyking is 15,3 . Dit is laer tellings as wat deur die bovermelde navorsers verkry is.

TABEL 4

BESRYWENDE STATISTIEK T.O.V. SELFDOELTREFFENHEIDVRAELYS VIR DIE TOTALE ONDERSOEKGROEP

\begin{tabular}{lccccc}
\hline ITEM & N & X & S & MIN & MAKS \\
\hline Selfdoeltreffendheid & 64 & 78,0 & 13,9 & 47,0 & 113,0 \\
\hline
\end{tabular}

Uit Tabel 4 blyk dit dat die gemiddelde telling wat op die Selfdoeltreffendheidsvraelys verkry is, 78,0 is, met 'n standaardafwyking van 13,9 . 'n Hoë gemiddelde telling van bo 91 op hierdie vraelys sou daarop dui dat die respondente 'n lae mate van selfdoeltreffenheid ervaar. 'n Telling van laer as 63 sou daarop dui dat 'n hoë mate van selfdoeltreffendheid ervaar word. Uit hierdie resultate blyk dat 'n gemiddelde mate van selfdoeltreffenheid ervaar word. So 'n telling hou implikasies vir die organisasie in deurdat daar gesê kan word dat die respondente slegs in 'n gemiddelde mate van mening is dat hulle selfdoeltreffend is. Dit beteken in die praktyk dat hulle slegs in 'n gemiddelde mate in hul eie vermoëns glo en slegs in 'n gemiddelde mate weet hoeveel tyd en energie aan sake in die werksopset te spandeer.

Tabel 5 dui aan dat die ondersoekgroep die hoogste gemiddelde telling op die subskaal interne lokus van beheer verkry het. Dit moet vermeld word die gemiddelde telling van outonomie 162,4 is, wat baie na aan die telling vir interne lokus van beheer is.

TABEL 5

BESRYWENDE STATISTIEK T.O.V. DIE LOKUS-VAN-BEHEERVRAELYS VIR DIE TOTALE ONDERSOEKGROEP

\begin{tabular}{lccccc}
\hline ITEM & N & X & S & MIN & MAKS \\
\hline Eksterne lokus van beheer & 63 & 98,0 & 22,0 & 44,0 & 152,0 \\
Interne lokus van beheer & 63 & 164,0 & 23,3 & 90,0 & 196,0 \\
Outonomie & 63 & 162,3 & 19,4 & 118,0 & 205,0 \\
\hline
\end{tabular}

Produkmomentkorrelasies is bereken om die sterkte van die liniêre verwantskap tussen veranderlikes in hierdie ondersoek te bepaal. Daar kon geen korrelasie gevind word tussen die totaaltelling van die Minnesota Tevredenheidsvraelys en die Interpersoonlike Vertrouevraelys nie.

TABEL 6

INTERKORRELASIES TUSSEN DIE ALGEMENE WERKSTEVREDENHEIDSTELLING EN SELFDOELTREFFENHEIDSTELLING

\begin{tabular}{ll}
\hline TEVREDENHEIDSDIMENSIE & SELFDOELTREFFENDHEID \\
\hline Werkstevredenheid: Totaal &,$- 30^{*}$ \\
Vermoë &,- 16 \\
Prestasie &,- 20 \\
Aktiwiteit &,- 13 \\
& \\
Bevordering &,- 15 \\
Outoriteit &,- 24 \\
Maatskappybeleid &,- 16 \\
& \\
Vergoeding &,- 24 \\
Medewerkers &,- 18 \\
Kreatiwiteit &,- 21 \\
Onafhanklikheid &,- 26 \\
Morele waardes &,- 17 \\
Erkenning &,- 28 \\
Verantwoordelikheid &,$- 30^{*}$ \\
Sekuriteit &,- 23 \\
Sosiale diens &,- 12 \\
Sosiale status &,- 19 \\
Toesighouding - mens &,- 24 \\
Toesighouding - tegnies &,- 05 \\
Verskeidenheid &,$- 31^{*}$ \\
Fisiese werksomgewing &,- 20 \\
\hline
\end{tabular}

Dit blyk uit Tabel 6 dat daar ' $n$ prakties betekenisvolle verband $(r=-0,30)$ tussen selfdoeltreffendheid en werkstevredenheid bestaan. Interkorrelasies is bereken ten opsigte van selfdoeltreffendheid en die twintig subfaktore van die Minnesota Tevredenheidsvraelys (kyk Tabel 6).

Dit blyk uit Tabel 6 dat daar 'n prakties betekenisvolle (negatiewe verband) bestaan tussen tevredenheid met verantwoordelikheid en verskeidenheid aan die eenkant en selfdoeltreffendheid aan die ander kant.

Tabel 7 toon dat daar ' $\mathrm{n}$ prakties betekenisvolle verband $(\mathrm{r}=$ 0,30 ) tussen outonomie (soos gemeet deur die LVB) en werkstevredenheid bestaan. Interkorrelasies is bereken ten opsigte van Eksterne Beheer, Interne Beheer en Outonomie en die twintig subfaktore van die Minnesota Tevredenheidsvraelys. 
TABEL 7

KORRELASIES TUSSEN LVB EN DIE MINNESOTA TEVREDENHEIDSVRAELYS

\begin{tabular}{|c|c|c|c|}
\hline Tevredenheidsdimensies & $\begin{array}{l}\text { Interne lokus } \\
\text { van beheer }\end{array}$ & $\begin{array}{l}\text { Eksterne lokus } \\
\text { van beheer }\end{array}$ & Outonomie \\
\hline Vermoë & 0,15 & 0,06 & 0,20 \\
\hline Prestasie & 0,26 & 0,10 & 0,28 \\
\hline Aktiwiteit & 0,15 & 0,01 & 0,11 \\
\hline Bevordering & 0,16 & 0,05 & 0,25 \\
\hline Outoriteit & 0,17 & 0,00 & 0,31 * \\
\hline Maatskappybeleid & 0,19 & $-0,07$ & 0,20 \\
\hline Vergoeding & 0,10 & $-0,22$ & 0,09 \\
\hline Medewerkers & 0,14 & 0,11 & 0,29 \\
\hline Kreatiwiteit & 0,29 & $-0,09$ & 0,31 * \\
\hline Onafhanklikheid & 0,15 & $-0,06$ & 0,21 \\
\hline Morele waardes & 0,29 & 0,09 & 0,21 \\
\hline Erkenning & 0,20 & $-0,05$ & $0,30^{*}$ \\
\hline Verantwoordelikheid & 0,28 & $-0,06$ & 0,33 * \\
\hline Sekuriteit & 0,13 & 0,14 & 0,20 \\
\hline Sosiale diens & 0,09 & $-0,04$ & 0,25 \\
\hline Sosiale status & 0,05 & $-0,06$ & 0,08 \\
\hline Toesig - mens & 0,05 & 0,19 & 0,09 \\
\hline Toesig - tegnies & 0,05 & 0,06 & 0,05 \\
\hline Verskeidenheid & 0,16 & $-0,6$ & 0,23 \\
\hline Fisiese werksomgewing & 0,06 & $-0,04$ & 0,14 \\
\hline
\end{tabular}

Dit blyk uit Tabel 7 dat daar 'n prakties betekenisvolle verband bestaan tussen outonomie en verantwoordelikheid, outoriteit, kreatiwiteit en erkenning.

Daar kan tot die gevolgtrekking gekom word dat outonomie op die Lokus van Beheervraelys dié subskaal is wat in 'n meerdere mate positiewe verbande toon met sommige subskale van die Algemene Tevredenheidsvraelys. Hierdie bevindinge korreleer met navorsing deur Kuhn, Murray en Atkinson (1982), wat 'n verband bevind tussen werkstevredenheid en lokus van beheer. Hoe hoër die mate van interne lokus van beheer is, hoe hoër is die mate van werkstevredenheid wat ervaar word. In dieselfde verband bevind Bernard (1997) dat daar ' $n$ positiewe verband tussen lokus van beheer en werkstevredenheid en laer stresvlakke bestaan.

Daar bestaan ' $\mathrm{n}$ prakties betekenisvolle (negatiewe) verband $(\mathrm{r}=-0,30)$ tussen interpersoonlike vertroue en selfdoeltreffendheid. Hoe hoër die individu se interpersoonlike vertroue, hoe hoër die mate van selfdoeltreffenheid wat ervaar word.

Wat betref die interkorrelasie tussen interpersoonlike vertroue en lokus van beheer, blyk dit in Tabel 8 dat daar 'n prakties betekenisvolle (negatiewe) verband $(\mathrm{r}=-0,30)$ tussen die subfaktor van eksterne lokus van beheer op die LVB-vraelys en interpersoonlike vertroue bestaan.

TABel 8

DIE INTERKORRELASIE TUSSEN INTERPERSOONLIKE-VERTROUETELLING EN LOKUS-VAN-BEHEERTELLING

\begin{tabular}{lccc}
\hline & $\begin{array}{c}\text { INTERNE LOKUS } \\
\text { VAN BEHEER }\end{array}$ & $\begin{array}{c}\text { EKSTERNE LOKUS } \\
\text { VAN BEHEER }\end{array}$ & OUTONOMIE \\
\hline $\begin{array}{l}\text { INTERPERSOONLIKE } \\
\text { VERTROUE }\end{array}$ & 0,01 & $0,30^{*}$ & $-0,05$ \\
\hline
\end{tabular}

Die kanoniese korrelasies is gedoen om die verband tussen die totale telling van lokus van beheer met die konstrukte werkstevredenheid, interpersoonlike vertroue en selfdoeltreffendheid te bereken. Hierdie kanoniese korrelasies word gerapporteer in Tabel 9.

TABEL 9

KANONIESE KORRELASIES TUSSEN LOKUS VAN BEHEER, WERKSTEVREDENHEID. INTERPERSOONLIKE VERTROUE, KOHERENSIESIN EN SELFDOELTREFFENHEID

\begin{tabular}{lcc}
\hline & LOKUS VAN BEHEER $(\mathrm{r})$ & WILKS' LAMDA $(\mathrm{p})$ \\
\hline Werkstevredenheid & $0,60^{* *}$ & $0,002^{*}$ \\
Interpersoonlike vertroue & 0,26 & 0,22 \\
Selfdoeltreffendheid & $0,79^{* *}$ & $0,002^{*}$ \\
Koherensiesin & $0,72^{* *}$ & $0,002^{*}$ \\
\hline
\end{tabular}

Die kanoniese korrelasie tussen lokus van beheer en werkstevredenheid is 0,60 . Dit bevestig dat daar 'n prakties betekenisvolle verband tussen lokus van beheer en werkstevredenheid bestaan. Hoër tellings ten opsigte van interne lokus van beheer en outonomie gekombineer met laer tellings ten opsigte van eksterne lokus van beheer hou dus verband met hoër werkstevredenheid (en omgekeerd).

\section{BESPREKING}

Die resultate van die empiriese ondersoek dui aan dat die werkstevredenheid van spanlede hoër is as dié wat in ander instansies gevind is (Coetzee, 1998). Wat die vlak van werkstevredenheid ten opsigte van die subfaktore van werkstevredenheid van spanlede aanbetref, kan die afleiding gemaak word dat respondente die minste tevredenheid ervaar ten opsigte van vergoeding, bevordering en erkenning. Die meeste werkstevredenheid word ervaar ten opsigte van morele waardes (die mate waarin werk verrig word wat nie teen morele oortuigings indruis nie); prestasie (die mate waarin vervulling in die werk ervaar word); en fisiese omgewing (die mate waarin werkers beleef dat die fisiese werksomgewing bevorderlik is vir werk).

Ten opsigte van interpersoonlike vertroue blyk dit dat die spanlede-ondersoekgroep oor 'n gemiddelde mate van interpersoonlike vertroue beskik.

Uit hierdie studie het dit geblyk dat lede van die ondersoekgroep 'n laer vlak van koherensie ervaar as wat in vorige navorsing gevind is (Wissing \& Van Eeden, 1997), en (Coetzee, 1998).

Ten opsigte van lokus van beheer blyk dit dat die lede van die ondersoekgroep ten opsigte van interne lokus van beheer laer as die gemiddelde tellings verkry het. Ten opsigte van eksterne lokus van beheer en outonomie is weer hoër as die gemiddelde tellings verkry. Daar kan tot die gevolgtrekking gekom word dat die lokus van beheer nie normaal versprei is binne die organisasie nie. Selfdoeltreffendheid is die enigste konstruk wat 'n normale verspreiding toon, en dit blyk dat die lede van die ondersoekgroep oor 'n redelike hoë mate van selfdoeltreffendheid beskik.

Die beperkings van hierdie navorsing is dat dit 'n relatiewe klein steekproef was $(\mathrm{N}=66)$. ' $\mathrm{n}$ Verdere beperking was dat daar van 'n beskikbaarheidsteekproef gebruik gemaak is, wat beteken dat bevindinge nie veralgemeen kan word nie. 


\section{AANBEVELINGS}

Die studie stel verskeie toepassingsaksies voor. Eerstens kan die organisasie individue aanstel wat oor 'n sterk koherensiesin, 'n lae eksterne lokus van beheer, 'n hoë mate van outonomiteit en 'n hoë mate van interpersoonlike vertroue beskik, afhangende van die spesifieke werk. Indien organisasies hierdie karaktereienskappe wil gebruik in selektering, is meer navorsing in hierdie verband nodig, aangesien hierdie eienskappe nie in die selekteringsproses bestudeer is nie.

Tweedens kan organisasies bydra tot die verhoging van spaneffektiwiteit deur werknemers op 'n konstante gestruktureerde wyse in te lig oor die voordele van spanwerk. Voorts behoort individue in staat te wees om eie spanrolle te identifiseer.

Derdens kan werknemers met die nodige kennis, vaardighede, materiaal, toerusting en ander hulpbronne toegerus word, sodat, hulle toenemend kan ervaar dat werkverwagtinge hanteerbaar en binne hulle en ander belanghebbende persone se vermoë is.

Vierdens behoort die hoër mate van selfdoeltreffendheid wat lede van die werkspanne ervaar positief aangewend te word in erkenning en outonomie ten opsigte van die werkspanne.

Vyfdens kan die vertroue wat in 'n mindere mate by die lede van die ondersoekspan teenwoordig was, ontwikkel word deur byvoorbeeld 'n beleid van deursigtigheid en deelnemende besluitneming te volg.

Laastens kan projekspanne saamgestel word oor al die vlakke van die organisasie, en aangestel word om spesifieke aanbevelings te doen.

\section{BRONNELYS}

Antonovsky, A. (1987). Unraveling the mystery of health: How people manage stress and stay well. San Fransisco, CA: JosseyBass.

Antonovsky, A. (1993). The structure and properties of the Sense of Coherence Scale. Social Science and Medicine, 36, 725-733.

Bandura, A. (1982). Self-efficacy mechanism in human agency. American Psychologist, 37, 122-147.

Bandura, A. (1986). Social foundations of thought and action: A social cognitive theory. Englewood Cliffs, NJ: Prentice-Hall.

Bandura, A. (1989). Human Afgency in social cognitive theory. American Psychologist, 44, 1175-1184.

Bandura, A. (1991). Self-regulation of motivation through anticipatory and self-reacvtive mechanisms. In: Diensttoer, R. (Ed.). Nebraska Symposium on motivation, 1990, (1) 38, University of Nebraska Press, Lincoln, UB, 64-164.

Barber, G. (1986). Correlates of job satisfaction among human service workers. Administration in Social Work, 10 (1), 25-37.

Baron, R.A., Byrne, D. \& Kantowitz, B.H. (1980). Understanding Behaviour. (2nd ed.). New York: Holt, Rienart and Winston.

Ben-Sira, Z. (1979). A scale of psychological distress. Research Communications in Psychology, Psychiatry and Behavior, 4, 337-356.

Ben-Sira, Z. (1988). Politics and primary medical care: Dehuminazation and overutilization. Aldershot: Averury.

Breed, M. (1997). Bepalende persoonlikheidstrekke in die salutogenetiese paradigma. Ongepubliseerde doktorale proefskrif, Universiteit van Suid-Afrika, Pretoria.

Butler, J. K. \& Cantrell, R. S. (1984). A behaviourial decision theory approach to modeling dydadic trust in the superiors and subordinates. Psychological Reports, 55, 19-28.

Chiu, R. K. \& Kosinki, F. A. (1977). Relationship between disposiitonal traits and self-reported job satisfaction and distress: An investigation of nurses and teachers in Hong Kong. Journal of Managerial Psychology, 12 (2), 71-84.

Coetzee, S. C. (1998). Aangeleerde vernuf, koherensiesin en werkstevredenheid. Ongepubliseerde Meestergraadskripsie, $\mathrm{PU}$ vir $\mathrm{CHO}$, Potchefstroom.
Coetzee, S. C. \& Rothmann, S. (1999). Die verband tussen koherensiesin en werkstevredenheid by bestuurders. Tydskrif vir Bedryfsielkunde, 25 (3), 31-38.

Cohen, J. (1988). Statistical power analysis for the behavioral sciences. $2^{\text {nd }}$ ed. Hillsdale, NJ: Lawrence Erlbaum \& Associates.

Cohen, S. G. \& Bailey, D. E. (1997). What makes teams work: Group effectiveness research from the shop floor to the executive suite. Journal of Management, 23 (3), 239-290.

Cohen, S. G. Ledford, G. E. \& Spreitzer, G. M. (1996). A predictive model of self-managing work team effectiveness. Human Relations, 49 (5), 643-676.

Cook, J. Hepworth, S., Wall, T. \& Warr, P. (1981). The experience of work. London: Academy Press.

Cranny, C. J. Smith, P. C. \& Stone, E. F. (1992). Job satisfaction: How people feel about their jobs and how it effects their performance. New York: Lexington Books.

De Waal, J. J. P. (1997). Gereedheid van toesighouers binne die goudmynbedryf vir die implementering van selfgerigte werkspanne. Ongepubliseerde meestersverhandeling. PU vir CHO, Potchefstroom.

Eden, D. (1988). Pygmalion, goalsetting, and expectancy: Compatible ways to boost productivity. Academy of Management Review, 13, 639-652.

Eden, D \& Zuk, Y. (1995). Seasickness as a self-fulfilling prophecy: Raising self-efficacy to boost performance at sea. Journal of Applied Psychology, 80, 628-635.

Gambetta, D. (1988). Can we trust? In trust: Making and breaking cooperative relationships. Cambridge: Blackwell.

Gardner, D. G. \& Pierce, J.L. (1998). Self-esteem and self-efficacy within the organisational context: An empirical examination Group and Organisation Management, 23, 48-70.

Garson, B. E. \& Stanwyck, D.J. (1997). Locus of control and incentive in self-managing teams. Human Resource Development Quarterly, 8 (3).

Gist, M. E. (1987). Self-efficacy: implcations for organisational behaviour and human resource management. Academy of Management Review, 12 (3), 472-485.

Gist, M. E. \& Mitchell, T. R. (1992). Self-efficacy, a theorectical analysis of its determinants and malleability. Academy of Management Review, 17 (2), 183-211.

Gladstein, D. L. (1984). Groups in context: A model of task group effectiveness. Administrative Science Quarterly, 29, 499-517.

Gould, W. B. (1993). Victor Frankl: Life with a meaning. Pacific Grove, CA: Brooks/Cole Publishers.

Hackman, J. R. (1987). The design of work teams. Handbook of Organisational Behaviour. Engelwood Cliffs, NJ: Prentice-Hall.

Hackman, J. R. \& Oldman, G. (1980). Work Design. Massachusetts. Addison-Wesley.

Heider, F. (1958). Psychology of interpersonal relations. New York: Wiley.

Holbreche, L. (1998). Motivating people in lean organizations. Oxford: Butterworth Heinemann.

Hosmer, L. T. (1995). Trust: the connecting lint between organisational theory and philosophical ethics. Academy of Management Review, 20 (2), 379-424.

Huysamen, G. K. (1993). Metodologie vir die sosiale- en gedragswetenskappe. Halfway House: International Thomson.

Jaques, E. (1970). Work, creativity, and social justice. New York: International University Press.

Jones-George, C. E. \& Swap, W. C. (1982). Measurement of specific interpersonal trust: Construction and validation of a scale to assess trust in a specific other. Journal of Personality and Social Psychology, 43, 1306-1317.

Judge, T.A. Locke, E.A. Durham, C.C. \& Kluger, A.N. (1998). Dis positional effects on job and life satisfaction: The role of core evaluations. Journal of Applied Pscyhology, 83, 17-34.

Kalimo, R. \& Vuori, J. (1990). Work and sense of coherence: Resources for competence and life satisfaction. Behavioural Medicine, 16, 76-89.

Kobasa, S.C. Madii, S.R. \& Kahn, S. (1982). Hardiness and health: A prospective study. Journal of Personality and Social Psychology, 42, 168-177. 
Kreitner, R. \& Kinicki, A. (1998). Organisational behaviour. (4 $4^{\text {th }}$ ed.). Boston, MA: McGraw-Hill.

Kren, L. (1992). The moderating effects of locus of control on performance incentives and participation. Human Relations, 45 (9), 991-1011.

Latham, G.P., \& Yukl, G.A. (1976). Effects of assigned and participative goal-setting on performance and job satisfaction. Journal of Applied Psychology, 61, 166-171.

Lawler, L. L. (1996). From the ground up: Six principles for building the new logic corporation. San Francisco, CA: Jossey Bass.

Lee, C. \& Bobko, P. (1994). Self-efficacy beliefs:Comparison of five measures. Journal of Applied Psychology, 79, 364-369.

Lefcourt, H. M. (1966). Internal versus external control of reinforcement. Psychological Bulletin, 63 (4), 206-220.

Lefcourt, H. M. Locus of control: Current trends in theory and research. New York: Wiley.

Locke, E. A. (1976). The nature and causes of job satisfaction. In M. D. Dunnette (Ed.), Handbook of industrial and organisational psychology, (pp. 1297-1350). Chicago, IL:Rand McNally.

Lofquist, L. H. \& Davis, R. V. (1969). Adjustment to work: A psychological view of many problems in a work-orientated society. New York: Appleton-Century-Crofts.

Marais, C. P. (1997). Salutogenesis as paradigm in change management. Ongepubliseerde meestersverhandeling. UNISA, Pretoria.

Marriot, F. H. C. (1974). The interpretation of multiple observations, London: Academic Press.

Mayer, R. C., David, J. R. \& Schoorman, F. D. (1995). An integrative model of organisational trust. Academy of Management Review, 20 (3), 709-734, July.

McAllister, D. J. (1995). Affect- and cognition-based trust as foundations for interpersonal cooperation in organisations. Academy of Management Journal, 38 (1), 24-59.

Mclagan, P. \& Nel, C. (1996). The shift to participation. People Dynamics, 14 (5), 12-17.

Mitchell, T. R. (1992). Self-efficacy: a theorectical analysis of its determinants and malleability. Academy of Management Review, 17 (2), 183-212.

Moerdyk, A. P. (1986). Planning and implementing a black advancement programe. In R. Smollan, (Ed.), Black advancement in South African economy (pp. 155-177). Houndmills, Basingstake:Macmillan.

Neubert, M. J. \& Mount, M. K. (1998). Relating member ability and personality to work-team processes and team effectiveness. Applied Psychology, 83 (3), 377-391.

Phares, E. J. (1976). Locus of control in personality. New York: General Learning Press.

Prussia, G. E., Anderson, J. S. \& Manz, C. C. (1998). Selfleadership and performance outcomes: The mediating influence of self-efficacy. Journal of Organizational Behavior, 19 (5), 523-538.

Rahim, M.A., \& Psenicka, C. (1996). A structural equation model of stress, locus of control, social support, psychiatric symptoms and propensity to leave a job. Journal of Social Psychology, 136, 69-84.

Robbins, S. P. (1998). Organisational behaviour. (5 $5^{\text {th }}$ ed.). Englewood Cliffs, NJ. Prentice-Hall.

Rothmann, S. \& Agathagelou, A. M. (2000). Die verband tussen lokus van beheer en werkstevredendheid by senior polisiepersoneel. Tydskrif vir Bedryfsielkunde, 2000, 26 (2), 20-26.

Rotter, J. B. (1966). Generalized expectancies for internal versus external control of reinforcment. Psychological Monographs, $80,1-28$.
Rotter, J. B., Chance, J. E. \& Phares, E. J. (1972). Applications of a social learning theory of personality. New York: Holt, Rhinehart \& Winston.

Roznowski, M. \& Hulin, C. (1992). The scientific merit of valid measures of general constructs with special references to job satisfaction and job withdrawel. In C. J. Cranny, P.C.

Smith, E. F. Stone, Job satisfaction: How people feel about their jobs and how it affects their performance (pp. 123-164). New York: Lexington Books.

Sadri, G. \& Roberson, I.T. (1993). Slef-efficacy and work-related behavior: A review and meta-analysis. Applied Psychology: An International Review, 42, 139-152.

SAS Institute. (1985). SAS Users Guide: Basics. $5^{\text {th }}$ ed. Cary, NC: SAS Institude Inc.

Schepers, J. M. (1999). Die Lokus van Beheer-vraelys: Konstruksie en evulering van 'n nuwe meetinstrument. Johannesburg: RAU.

Seeman, M. \& Seeman, T.E. (1983). Health behaviour and personal autonomy: A longitudinal study of sense of control in illness. Journal of Health and Social Behaviour, 24, 144-160.

Schwoerer, C.E. \& May, D.R. (1996). Age and outcomes: The moderating effects of self-efficacy and tool design effectiveness. Journal of organisatinal Behaviour, 17, 469-487.

Sherer, M. \& Maddux, J. D., Mercandante, B., Prentice-Dunn, S., Jacobs, B. \& Rogers, R. W. (1982). The self-efficacy scale: Construction and validation. Psychological Reports, 51, 663-671.

Sitkin S.B. \& Roth, N. L. (1993). Explaining the limited effectiveness of legalistic "remedies" for trust/distrust. Organisation Science, 4, 367-392.

Spector, P. E. (1986). Perceived control by employees: A metaanalysis of studies concerning autonomy and participation at work. Human Relations, 39, 1005-1016.

Staw, B. M. \& Roth, N. L. (1993). Stability in the midst of change: a dispositional approach to job attitude. Journal of Applied Psychology, 70 (3), 469-480.

Steyn, H. S. (1999). Praktiese beduidendheid. Die gebruik van effekgroottes. Potchefstroom: PU vir CHO.

Strümpfer, D. J. W. (1995). The origins of health and strength: from saltutogenesis to fortigenesis. South African Journal of Psychology, 25 (2), 81-89, Jun.

Strümpfer, D. J. W., Danana, N., Gouws, J. F. \& Viviers, M.R. (1998). Personality dispositions and job satisfaction. South African Journal of Psychology, 28 (2), 92-99.

Strümpfer, D. J. W., Fritz, G. \& Page, M.J. (1991). Relationship of sense of coherence to health and work in data processiing personnel. Unpublished report, Department of Psychology, University of Cape Town.

Sundstrom, E., De Meuse, K. P. \& Futrell, D. (1990). Work teams. American Psychologist, 45 (2), 120-133.

Tipton, R.M. \& Worthington, E.L. (1984). The measurement of generalised self-efficacy: A study of realibility and validity. Journal of Personality Assessment, 48, 545-548.

Weiss, H., Davis, R., England, G. \& Lofquist, L. (1967). Manual for the Miinesota satisfaction questionnaire. Industrial Relations Centre, University of Minnesota.

Wege, J. W. \& Möller, A. T. (1995). Effectiveness of a problemsolvinf training program. Psychological Reports, 76, 507-514.

Wissing, M. P. \& Van Eeden, C. (1997). Psychological well-being: A fortigenic conceptualization and empircal clarification. Paper presented at the $3^{\text {rd }}$ Annual Congress of the Psychological Society of South Africa Durban, 10-12 September, 1997.

Wood, R. \& Bandura, A. (1989). Social Cognitive Theory of organisational management. Academy of Management Review, 14 (3), 361-384. 